\title{
GCU
}

Glasgow Caledonian

University

University for the Common Good

\section{Cochrane overviews: How can we optimize their impact on evidence-based} rehabilitation?

Pollock, Alex; van Wijck, Frederike

Published in:

European Journal of Physical and Rehabilitation Medicine

DOI:

10.23736/S1973-9087.19.05780-0

Publication date:

2019

Document Version

Author accepted manuscript

Link to publication in ResearchOnline

Citation for published version (Harvard):

Pollock, A \& van Wijck, F 2019, 'Cochrane overviews: How can we optimize their impact on evidence-based rehabilitation?', European Journal of Physical and Rehabilitation Medicine, vol. 55, no. 3, pp. 395-410. https://doi.org/10.23736/S1973-9087.19.05780-0

\section{General rights}

Copyright and moral rights for the publications made accessible in the public portal are retained by the authors and/or other copyright owners and it is a condition of accessing publications that users recognise and abide by the legal requirements associated with these rights.

Take down policy

If you believe that this document breaches copyright please view our takedown policy at https://edshare.gcu.ac.uk/id/eprint/5179 for details of how to contact us. 
TITLE: Cochrane overviews: how can we optimise their impact on evidence-based rehabilitation?

\section{AUTHORS:}

Dr Alex Pollock*, Nursing Midwifery and Allied Health Professions (NMAHP) Research Unit, Glasgow Caledonian University, UK

Professor Frederike van Wijck, School of Health and Life Sciences, Glasgow Caledonian University, UK

*Corresponding author

CORRESPONDENCE ADDRESS:

Dr Alex Pollock

Nursing, Midwifery and Allied Health Professions (NMAHP) Research Unit

$6^{\text {th }}$ Floor, Govan Mbeki Building

Glasgow Caledonian University

Glasgow G4 OBA

EMAIL: alex.pollock@gcu.ac.uk 


\section{ABSTRACT}

\section{Background}

Overviews (i.e. reviews of multiple systematic reviews) comprise a relatively novel methodology to systematically synthesise research findings. Overviews aim for a beneficial impact on clinical practice, but their methods and pathways to impact have so far not been mapped.

$\underline{\text { Aim }}$

To inform recommendations for optimising impact on rehabilitation practice and research by mapping methods and pathways to impact in Cochrane overviews relevant to rehabilitation.

\section{Methods}

We systematically searched and identified published Cochrane overviews (to June 2018) relevant to rehabilitation. We extracted data and compared overviews on key characteristics, methods of evidence synthesis, statements about impact, and access metrics. We explored one overview in detail regarding beneficiaries, activities and outputs, mapped potential pathways to impact, and, using an iterative process, refined this into a generic map. Through exploration of all synthesised data, we propose further recommendations for planning, conducting and reporting of future overviews in order to optimise impact on rehabilitation.

\section{$\underline{\text { Results }}$}

We identified seven Cochrane overviews relevant to rehabilitation. Their focus and methods varied, but they were broadly related to rehabilitation interventions for populations of people with diverse long term conditions. Overviews also varied regarding their intended impact; only 4 overviews identified specific beneficiaries. All overviews included multiple tables and figures, but only one synthesised key findings into a single figure. For five overviews, the Altmetric Attention Score (a weighted count of attention that an output receives based on a range of online sources) was in the top $5 \%$ of all research outputs scored by 
Altmetric. The overview within our worked example had four key impact goals, each with different beneficiaries and required actions; this example led to a generic map of potential pathways to impact for other overviews.

\section{Conclusions}

Cochrane overviews have the potential to play a key role in knowledge translation and therefore to be useful in supporting evidence-based rehabilitation practice. However, current overviews relating to rehabilitation differ in methods, approaches and intended impact, and sometimes fall short of promoting easy access to key information for beneficiaries. Future Cochrane overviews should address topics of importance to key beneficiaries and clearly outline potential pathways to impact in order to have a potential beneficial impact on evidence-based rehabilitation and to improve rehabilitation outcomes.

\section{KEY WORDS}

Rehabilitation, evidence-based practice, evidence-based medicine, review, systematic review, systematic review as topic, literature review, clinical trial overviews, social impact 


\section{MAIN TEXT}

\section{INTRODUCTION}

Systematic reviews use established, robust research methods to find and bring together, in an explicit and transparent way, all the research evidence that addresses a particular topic or question. In the field of health and social care, by systematically and comprehensively identifying, appraising and synthesising evidence relating to the effectiveness of interventions, systematic reviews are considered to play a central role in informing and supporting evidence-based practice. ${ }^{1}$ High quality systematic reviews which aggregate (i.e. statistically combine using meta-analysis) data from a number of similar studies are widely recognised to provide the best source of evidence to inform decision making. ${ }^{2,3}$ The publication rate of systematic reviews of healthcare interventions is rapidly increasing $;{ }^{4}$ in 2014 it was estimated that $>8000$ systematic reviews were indexed on MEDLINE and that around 22 new systematic reviews were being published every day. ${ }^{5}$ In August 2018 there were 9471 Cochrane systematic reviews and protocols available within the Cochrane Library of which 9.4\% (894) were directly relevant to rehabilitation. ${ }^{6}$

While high quality systematic reviews are desirable and potentially beneficial to the delivery of optimal healthcare interventions, including rehabilitation, the rapidly increasing number of systematic reviews can be overwhelming for healthcare decision makers. ${ }^{7,8}$ In response to this, systematic reviews of systematic reviews are being produced, using new and evolving methodologies. ${ }^{9-11}$ These are referred to as "overviews" (or sometimes also "umbrella reviews" or "meta-reviews"), and involve systematically identifying, appraising and synthesising the results of multiple systematic reviews in order to inform and support decision making. ${ }^{10,12-15}$

Overviews generally have a goal of providing a summary of evidence, signposting evidence within systematic reviews in order to support healthcare decision making, although there can be considerable variation in the specific aims of individual overviews. ${ }^{10,15,16}$ Overviews generally address broader research questions than systematic reviews, ${ }^{17}$ exploring the effects of different interventions for the same population or problem ${ }^{17,18}$ or the same intervention for different populations or problems. ${ }^{18,19}$ Overviews 
may examine reasons for discordant review findings ${ }^{20,21}$ and/ or identify research gaps. ${ }^{18,21}$ By fulfilling these various aims, overviews can effectively summarise the known evidence relating to a broad topic or issue, and can play a key role in directing healthcare decision makers to sources of more detailed information, including systematic reviews and primary research. ${ }^{21-24}$ Further, overviews have been proposed to play an important role in the avoidance of research waste. ${ }^{17}$

Overviews are a new and developing methodology and there is currently considerable variation in their methods. While some of the methods for overviews are shared with established methods for systematic reviews, ${ }^{25}$ there are unique methodological challenges within overviews for which best practice has not yet been established. ${ }^{14,16,21,22,26-28}$ Recent evaluations have highlighted inconsistencies and gaps in current guidance for methods for conducting overviews ${ }^{14,16,26}$ and lack of evidence to support selection of optimal methods for individual overviews. ${ }^{16,25}$ Work is underway to summarise current evidence and develop guidance relating to the conduct and reporting of overviews. ${ }^{16,25,29,30}$

Cochrane Rehabilitation aims to ensure that rehabilitation professionals have the best-available information to support evidence-based practice. ${ }^{31}$ Overviews of rehabilitation reviews may be able to support this aim, although the potential pathways from overview to impact are currently unclear. The term "impact" may be interpreted in different ways, and can incorporate academic advances, or societal or economic contributions, which relate to improving practice; ${ }^{32}$ Cochrane Rehabilitation's knowledge translation strategy ultimately aims for evidence from Cochrane reviews to have an impact on decisionmaking in rehabilitation. ${ }^{33,34}$ For the purpose of this paper, we defined "impact" according to the Research Councils in the UK: academic impact is defined as "the demonstrable contribution that excellent research makes to academic advances, across and within disciplines, including significant advances in understanding, methods, theory and application", while societal and economic impact is defined as "the demonstrable contribution that excellent research makes to society and the economy". ${ }^{32}$ Using these definitions, we considered that the impact of an overview could be expressed as academic advances conveyed in outputs, such as publications, as well as changes that happen in the real world (beyond the world of researchers). ${ }^{35}$ The goal of this paper is to explore how Cochrane overviews of reviews may generate impact, both on 
clinical decision making in rehabilitation (i.e. societal/ economic impact) and research (i.e. academic impact). The specific aims are to:

1. Describe, compare and contrast key features of published Cochrane overviews relevant to rehabilitation, i.e. methodological characteristics (such as selection criteria, data extraction and reporting) and statements of intended impact;

2. Discuss the potential role of Cochrane overviews in supporting evidence-based rehabilitation by exploring the anticipated impact of one Cochrane overview as a worked example;

3. Provide recommendations for optimising the impact arising from Cochrane overviews.

\section{MATERIALS AND METHODS}

We systematically searched for and identified published Cochrane overviews relevant to rehabilitation, and extracted and synthesised data relating to key methodological characteristics and expressions of anticipated impact (on practice and research) of these overviews. We conducted additional data extraction and evaluation relating to the outputs and impact of one overview which we had authored, to stimulate discussion on generating impact based on a worked example. Emerging findings, relating to methods, output and impact of overviews, informed a discussion about the role of Cochrane overviews in evidencebased rehabilitation. Based on this, a number of recommendations for optimising the impact of Cochrane overviews were proposed, which are illustrated in a model. Key stages are described below:

\section{Search methods}

We searched the Archie database, version 4.18 on $18^{\text {th }}$ June 2018; Archie is Cochrane's central system for Cochrane authors and review groups, enabling management of individual reviews and portfolios of reviews by review groups. We used the "Advanced Search" function, searching documents for reviews of type "overviews of reviews" and with a publication status of "published". We exported the search results into Excel. To be included the following criteria had to be met: full published overview, synthesising evidence relating to one or more rehabilitation interventions. We used the WHO definition of rehabilitation: 
"Rehabilitation is characterized by interventions that address impairments, activity limitations and participation restrictions, as well as personal and environmental factors (including assistive technology) that have an impact on functioning" ${ }^{36}$ Two authors independently applied the inclusion criteria, with any disagreements resolved through discussion. First, each author independently screened the titles and excluded any overviews judged to be focussed only on pharmacological or surgical interventions. Second, each author independently assessed abstracts and, if necessary, full papers for all remaining titles. At this stage published protocols, which were not yet completed, and overviews which had been withdrawn from publication were excluded. All remaining overviews were assessed to determine if they met the criterion of synthesising systematic review evidence focussed on one or more rehabilitation interventions. Reasons for excluding overviews, any disagreements between authors and final consensus decisions were documented.

\section{Data extraction}

For all included overviews we systematically documented key methodological characteristics, using headings previously adopted to describe overview methods. ${ }^{21}$ These included: aim/question of overview, inclusion criteria (participants, interventions, outcomes, type of study), databases searched, any updating of out of date reviews, methods of selecting reviews, data extracted, tool or method for assessing quality of reviews, approach or method for assessing quality of evidence within reviews, description of how evidence was synthesised, details of any statistical analyses (planned or carried out), and description of how key findings were presented. For each included overview we extracted key results data, including: number of included reviews, number of reviews with data extracted (and whether these were Cochrane or nonCochrane reviews), number of included primary studies (in the overview), number of RCTs and participants within included reviews, and the number of included reviews directly relevant to rehabilitation.

To explore the intended impact of the included overviews we sought and extracted information relating to different types of impact. For societal/ economic impacts, we extracted statements about the purpose of the overview relating to rehabilitation practice, and any statements on the anticipated implications of the findings for practice. For academic impacts, we extracted statements about the purpose of the overview relating to research, and any statements on the anticipated implications for research. Further, as the 
purpose of overviews has been described as "mapping"16, 23, 37 or "sign-posting"11, 18, 21 evidence, broadly referring to the act of "summarising broad issues and current knowledge around a topic, and directing a reader to more detailed, fine-grained material contained in component systematic reviews and primary research"11 we documented in what way this was done.

To measure academic impact in terms of the uptake of the overviews, we extracted data relating to article metrics, including the number of times the overview was cited (via Web of Science,

https://clarivate.com/products/web-of-science), the Altmetric Attention Score (a weighted count of all the attention a research output receives based on number of mentions within a range of online sources including public policy documents, media outlets, blogs and social media posts) (www.altmetric.com) and the number of full-text downloads during 2016 (from a summary of review metrics produced by Cochrane $\left.{ }^{38}\right)$.

\section{Data synthesis}

For all included overviews, we summarised the extracted data within tables, and produced a narrative account highlighting key differences and similarities in the methods of the included overviews, and their descriptions of intended impact.

We then selected one overview, completed by the author team, ${ }^{39}$ in order to allow a more in-depth exploration of its impact, including both impact on practice and on research. We reached consensus on impact goals, based on goals stated within the published overview. We noted the potential beneficiaries of each of our identified impact goals, and evidence of any specific activity or output which demonstrated achievement of the impact goal. For academic impact, we extracted evidence directly attributed to this overview from the ResearchFish Database (https://www.researchfish.net/), which contained routinely collected details of the outputs arising from this overview, updated on an annual basis from 2014 (last update March 2018).

Based on impacts identified through the worked example, we used definitions of impact types, from UK Research Excellence Framework, ${ }^{32,40}$ to inform the development of a generic map of potential pathways to 
impact from Cochrane overviews in the field of rehabilitation. This involved an iterative process; we first mapped the impact goals, beneficiaries and intended actions from the worked example, which was specific to arm recovery in people after stroke. We considered each of the outputs listed within the ResearchFish database and entered these into a draft visual representation of the pathways to impact. Next we discussed the wider implications of the mapped pathways to impact relating to our worked example, specifying in generic language the intended types of impact, beneficiaries and actions required, and their interaction. Further discussion and refinement led to a generic map of proposed pathways to impact for any Cochrane overview in the field of rehabilitation.

We conclude this paper with a narrative discussion exploring the potential impact of Cochrane overviews on the delivery of evidence-based rehabilitation, including research to provide new evidence, using earlier results to support key points. We propose a number of recommendations for optimising the potential to achieve a beneficial impact from Cochrane overviews on rehabilitation.

\section{RESULTS}

\section{Results of the search}

We considered 59 published Cochrane overviews; seven met our criteria for being a published Cochrane overview relevant to rehabilitation, ${ }^{39,41-46}$ and were included (see Figure 1, and Table of excluded overviews (Supplementary Digital Material: Appendix 1)).

\section{Cochrane overviews relevant to rehabilitation}

\section{(1) Overview methods}

Table I provides a summary of key characteristics of the methods of the included overviews. All seven of the overviews aimed to summarise evidence relating to the effectiveness of a group of interventions for a specific population of participants (see Table I for details). Three of the seven overviews were focussed specifically on rehabilitation interventions, ${ }^{39,41,42}$ while four considered a broad range of different types of intervention (i.e. pharmacological and/or surgical, as well as rehabilitation interventions). ${ }^{43-46}$ Five of the 
overviews pre-stated outcomes of interest; ${ }^{39-44}$ one overview included any outcomes as reported in the individual Cochrane reviews, and categorised these according to the ICF; ${ }^{45}$ and one overview defined outcomes of interest within the methods but did not report data relating to these, instead narratively reporting outcomes reported in individual trials. ${ }^{46}$ All overviews reported adverse events, where this information was reported in their included studies. Only three overviews included outcomes relating to costs or cost-effectiveness. ${ }^{41,45,46}$

Search strategies, and actions relating to how up-to-date reviews were, varied across the included overviews. Three of the overviews only included Cochrane reviews and, within these, searching was limited to the Cochrane Database of Systematic Reviews (CDSR), withno action taken to update searches of Cochrane reviews which were out of date. ${ }^{41,42,44}$ Three of the overviews searched for non-Cochrane reviews in addition to Cochrane reviews, searching a number of electronic databases in addition to CDSR; ${ }^{39}$, ${ }^{44,46}$ despite searching, one of these overviews ${ }^{46}$ did not include any non-Cochrane reviews. Two overviews searched multiple electronic databases for randomised controlled trials, in addition to searching for Cochrane ${ }^{43}$ and non-Cochrane reviews ${ }^{46}$, in order to identify any trials which were not included within a review.

The inclusion of non-Cochrane reviews in addition to Cochrane reviews introduces methodological challenges associated with how to deal with issue of overlapping reviews (i.e. two or more reviews synthesising the same, or similar, evidence). The approach taken within the two overviews including nonCochrane reviews differed; one selected the most up-to-date (and high quality) evidence, after appraisal of both Cochrane and non-Cochrane reviews, ${ }^{39}$ while the other only sought a non-Cochrane review which was more up-to-date than a Cochrane review on the same topic. ${ }^{44}$ One overview avoided the issue of overlap by only including Cochrane reviews, and addressed the issue of up-to-dateness by supplementing included Cochrane reviews with randomised controlled trials which were published after the search date of the Cochrane review, identified through searching the review group trials register. ${ }^{43}$ The overview authors stated that they originally planned to "update Cochrane reviews with new studies identified for inclusion", but found there were challenges which precluded them from doing this. ${ }^{43}$ There were similarities in the 
selection methods for all overviews, with - as is considered appropriate within systematic review methodology - two independent authors applying inclusion criteria to identify relevant reviews. However, this approach was not used for the selection of trials within the overview including primary studies, where only one author was involved in trial selection. ${ }^{43}$

Six of the seven overviews extracted and reported key characteristics of the included reviews, such as inclusion criteria, search strategies, and some details pertaining to the review results (e.g. number of included studies, participant demographic variables). ${ }^{39,41-45}$ One of the overviews also extracted data relating to the individual trials included in the reviews. ${ }^{41}$ The seventh overview identified RCTs included within the reviews and extracted and reported (limited) characteristics of these, without describing the characteristics of the reviews. ${ }^{46}$ Five of the overviews systematically extracted the results of meta-analyses in the review, where these had a relevant intervention and outcome, and reported these results within a series of detailed tables. ${ }^{39,41-44}$ One overview presented results in a narrative format, without systematic extraction of meta-analysis results, ${ }^{45}$ while one focused on the results of the included trials rather than reporting any results from the individual reviews ${ }^{46}$.

Quality assessment methods showed similarities, with all seven of the overviews using two independent authors using the AMSTAR (or a modified version) to assess quality of the review methods. Six of the seven overviews used the GRADE approach to assess the quality of evidence within the reviews, with two using explicit/objective criteria to inform downgrades. ${ }^{39,44}$ One overview grouped the quality of evidence in the included reviews into "tiers", based on explicit criteria relating to methods, risk of bias and outcomes. ${ }^{42}$

\section{(2) Overview results}

Table II provides a summary of the quantity of evidence included within each overview. This table also shows variation of sources included, with five overviews ${ }^{41-43,45,46}$ including only Cochrane reviews and two overviews $^{39,44}$ including both Cochrane and non-Cochrane reviews. Six of the overviews reported the effects of interventions using a narrative account of the results of the reviews, supported by tables, whilst one ${ }^{46}$ focused on the results of the individual trials identified from the reviews. There were differences in 
the way in which results for the "effects of interventions" had been structured and presented, with two overviews structuring narrative summaries around each outcome of interest, ${ }^{42,43}$ two overviews structuring narrative summaries around different interventions, ${ }^{39,44}$ one overview grouping evidence according to whether interventions act at the level of "impairment" or "activity and participation" 45 , one overview describing the key results of each individual included review, ${ }^{41}$ and one overview describing the key results from individual trials. ${ }^{46}$ Five of the overviews summarised effect size data within tables. ${ }^{39,41-44}$ There were similarities in tabulated data although differences in how this was presented, with reported data including: intervention, comparison, outcome, number of trials and participants, effect size, P-values and confidence intervals. Two overviews illustrated effect size visually, within at least one forest plot. ${ }^{39,44}$ One overview pooled the effect sizes for individual trials, using data extracted by overview authors from trials identified in reviews. ${ }^{44}$ In contrast, one overview plotted pooled effect size data as presented in different reviews in order to provide a visual representation of effect sizes for different interventions compared with control, for the same outcome measure. ${ }^{39}$

\section{(3) Overview impact}

Table III provides a summary of the intended impacts, reported within the overviews. Intended beneficiaries were identified as clinicians, ${ }^{39,45,46}$ policy makers, ${ }^{39,45}$ people with the condition, ${ }^{46}$ informed consumers, ${ }^{45}$ readers, ${ }^{44}$ and researchers. ${ }^{46}$ Three of the overviews did not seem to identify specific beneficiaries. ${ }^{41-43}$ Intended actions to generate impact on practice included directing readers, ${ }^{39,44}$ aiding decision-making, ${ }^{39}$ providing evidence for intervention delivery, ${ }^{41}$ but such actions did not seem to be explicit in the remaining overviews. ${ }^{42,43,45,46}$ Intended actions to bring about impact on research included; making recommendations for future research, ${ }^{39,41-43,45,46}$ identifying opportunities for merging or splitting existing Cochrane reviews, ${ }^{41}$ making recommendations for the use of outcome measures for future research, ${ }^{43}$ evaluating the interpretation of the evidence in published reviews, ${ }^{42}$ whilst there appeared to be no mention of intended impact on research in the remaining overview. ${ }^{44}$

The method for "signposting" or "mapping" varied widely, as Table III indicates. All overviews aimed to synthesise information from different reviews, while four additionally stated that their purpose was to 
produce an accessible ("usable" or "friendly front-end") document. ${ }^{39,41,44,45}$ All overviews included multiple tables and/ or figures, but only one ${ }^{39}$ included a single figure that listed each intervention, the quality of the underpinning evidence and key outcomes, together with the evidence source.

The implications of findings for practice varied considerably, ranging from specific, evidence-based recommendations for treatment delivery ${ }^{39,43}$ and confirmation of evidence supporting guidelines ${ }^{41}$ to calls for a cautionary approach given a lack of evidence. ${ }^{39,42,44,45}$ One overview ${ }^{46}$ did not identify any reviews related to rehabilitation interventions and therefore no implications for practice or research could be extracted.

The implications of the findings for research also varied, from general methodological recommendations to improve future research, ${ }^{41,43,44}$ specific recommendations for future reviews and/ or clinical trials, ${ }^{39,42-44}$ recommendations to establish a national/ international organisation around patient values to improve the evidence base, ${ }^{43}$ to develop an agreed, appropriate set of outcome measures ${ }^{42,43,45,46}$ and time points, ${ }^{46}$ and to cover the entire spectrum of care ${ }^{45}$ in future research. Two overviews ${ }^{39,44}$ also recommended collaborative working in future research, thereby avoiding research waste ${ }^{39}$ or improving recruitment. ${ }^{44}$ One overview ${ }^{39}$ suggested that it could inform prioritisation of future research.

\section{(4) Overview Uptake}

The uptake of overviews, by different readers using different communication channels, can be captured in a range of metrics. Table IV summarises an array of different key access data for each of the seven overviews, illustrating substantial variation between them.

\section{Case study: Impact of Stroke Upper Limb Overview}

One overview ${ }^{39}$ was used as a worked example to explore impact on research and practice in more detail. Exploration of the stated aims and objectives of this overview ${ }^{39}$ led to consensus that there were four key impact goals, each with different potential beneficiaries. 
These were: (1) Support decision making for stroke rehabilitation (beneficiaries: clinicians, service managers, policy makers), (2) Inform evidence-based practice through service design and/or delivery (beneficiaries: policy makers, professional bodies and networks, and governments), (3) Inform future research (beneficiaries: researchers and research funders), and (4) Improve outcomes and experiences for stroke survivors and their families (beneficiaries: patients, carers, families).

Documented outputs (see Supplementary Digital Material: Appendix 2) suggest that evidence within the overview informed evidence-based clinical practice through impact on national guidelines (e.g. the overview is cited in RCP National Clinical Guideline for Stroke $2016^{47}$ ), and informed parliamentary personnel following a presentation to national government (see "Engagement activities" in Appendix 2). A series of presentations to health professionals working in stroke care, and the dissemination of a summary document signposting health professionals to relevant systematic reviews, was designed to impact on decision making of clinicians; feedback gathered from participants indicated that they intended to change their behaviour as a result of the information that they received but there was no formal evaluation of impact (see "Project details" in Appendix 2). Primary research studies, subsequent to this overview, have cited research recommendations from the overview, evidencing academic impact (see "Subsequent funding" in Appendix 2). The goal of improving stroke survivor outcomes was considered to be dependent on successful achievement of the previous three goals, but evidence of this impact is yet to be established.

\section{Towards a map of potential pathways to impact}

We mapped the pathways to impact from the above worked example, and then refined this into a generic map of potential impacts and pathways to impact for any overview on rehabilitation. This map is presented in Figure 2.

\section{DISCUSSION}

There are currently seven Cochrane overviews focussed on topics relevant to rehabilitation, although only six of these included evidence relevant to rehabilitation. The focus and methods of these overviews vary, but they are broadly related to rehabilitation interventions for populations of people with diverse long term 
conditions. A stated aim of all of these overviews was to bring together and document evidence relating to a range of interventions, and all overviews included at least one summary table, providing access to (or "signposting" clinicians to) relevant evidence. However, while it was common for overviews to state that they aimed for an impact on evidence-based rehabilitation, their intended pathway to this impact was not always clear. Similarly, most overviews (six out of seven) stated that they aimed to have an impact on research, either by identifying gaps in research or establishing recommendations for future research, but the intended pathway to this impact on research was not always clear; only three overviews explicitly described a method to determine research gaps or recommendations. There were some further differences between the stated purpose relating to impact on research, with some overviews stating additional aims, such as determining whether to merge or split Cochrane reviews, or to make recommendations relating to reporting of standard outcomes. The differences in stated overview aims or purpose did not appear to fully explain the variations in methods between overviews, and the intended pathways to impact were generally unclear.

There was evidence of uptake of academic outputs, with five of the seven overviews being in the top $5 \%$ of research outputs scored by Altmetric. These Altmetric scores highlight that many overviews are being accessed as a result of social media dissemination, rather than by traditional journal publication only. However, it was noted that few of these overviews explicitly addressed the ways in which the overview could potentially support evidence-based rehabilitation. Interpretation of this finding should be cautionary as the absence of reporting does not mean that overview authors did not consider the intended impact of the overview; arguably this may reflect use of the reporting template provided by Cochrane. Given that Cochrane overviews are a relatively new product and that there is a known lack of guidance relating to methods and reporting of overviews, ${ }^{14,16,21,25,26}$ it is perhaps not surprising that there are variations within these overviews in terms of the main approach to evidence synthesis and summary.

We also carried out a more in-depth exploration relating to one particular overview, focussed on interventions to improve upper limb function after stroke, and charted evidence of activities and outputs which have potential to have a beneficial impact on outcomes for stroke survivors, through enhanced 
support for decision making and informed practice and research. Impact on stroke survivor outcomes arguably the most important goal of the overview - is arguably one of the most difficult types of impact to capture and attribute, as it is dependent on multiple influences, such as patient preferences, staff skills and local resources, and would require complex evaluation processes using validated outcomes.

If Cochrane overviews are to have a beneficial impact on evidence-based rehabilitation, it would appear crucial that careful consideration is given to how the overview will support this. We believe that it would be advantageous to the facilitation of beneficial societal, economic and academic impacts from overviews if clear descriptions of impact goals, beneficiaries, and proposed pathways to impact were clearly and transparently stated within Cochrane overviews (and protocols for overviews). We have proposed a generic map as a way to begin to support consideration and charting of potential pathways to impact, but this will require further development and refinement. Integrating clearly stated impact goals, and proposing and implementing strategies designed to meet these goals, would be an important step towards ensuring that future overviews can support the delivery of evidence-based care.

Given the broad range of populations who receive rehabilitation interventions, and the number of Cochrane reviews relevant to rehabilitation, it is apparent that the current Cochrane overviews only cover a very small proportion of potentially relevant topics. However, overviews are a relatively new methodology and numbers are increasing; our search identified 11 protocols, some of which have now progressed to full overview (including overviews relevant to rehabilitation: see Supplementary Digital Material: Appendix 1). Exploration of Cochrane reviews relating to rehabilitation highlights that there are many "clusters" of reviews which could potentially be brought together within an overview in order to enhance accessibility to related evidence. For example, future overviews could summarise evidence from "clusters" of reviews of: different interventions for specific topics, such as low back pain; single intervention for different populations, such as transcutaneous electrical stimulation; interventions or care delivered by one allied health professional group, such as speech and language therapy (see Supplementary Digital Material: Appendix 3, for three examples of "clusters" of Cochrane reviews). Evidence from the completed overviews, and knowledge of the existence of many clusters of Cochrane reviews, contribute to the 
argument that Cochrane overviews could potentially play an important role in providing a "friendly front end" to evidence addressing a range of rehabilitation interventions for a particular population, condition or problem. Such Cochrane overviews could clearly signpost the existing reviews, and increase accessibility and knowledge of this valuable evidence base.

However, counter to this, healthcare decision makers already report feeling overwhelmed by the high and rapidly increasing numbers of research publications and it is crucial that production of overviews of reviews serve as a solution to this problem, rather than simply adding to the insurmountable volume of evidence. While overviews have been proposed to have a role in the avoidance of research waste there is clearly a risk that the opposite occurs, and overviews contribute to research waste, producing inaccessible and complex documents. Printed versions of these seven rehabilitation overviews vary in length from 43-172 pages, demonstrating that these are lengthy, rather than brief summary, documents; and our experience of reading and synthesising information from these overviews highlighted inconsistencies in reporting and lack of clear indexing which were barriers to accessibility. Further, to be of use, evidence needs to be upto-date, and consequently it is important that overviews are maintained and updated, ensuring inclusion of and signposting to, the most up-to-date evidence. Five of the seven overviews did nothing to update the included reviews, while the sixth identified recent randomised controlled trials but the authors found they were unable to incorporate these into the existing reviews. Cochrane has recently introduced "Living systematic reviews" into the Cochrane Library; ${ }^{48}$ embarking on the development and maintenance of "living overviews" could be an important step toward efficient, timely overviews which remain useful and up-todate.

\section{Recommendations for future overviews}

Exploration of current overviews relating to rehabilitation highlights that there are variations in aims, methods, reporting and activities to support knowledge translation and impact. It is essential that authors planning to conduct new overviews are aware of the rapidly evolving body of evidence and guidance relating to the conduct and reporting of overviews (e.g. ${ }^{16,25,29,30}$ ) and use latest guidance to inform the selection of optimal methods. It is important to remain cognisant of the fact that the objective of an 
overview is to support knowledge translation, and therefore differs from the objective of an individual systematic review. If overviews are to be accessible and useful, it is essential that key stakeholders are involved in identifying priority topics for overviews and planning and implementing bespoke knowledge translation strategies, ${ }^{11,21,49}$ tailored to their intended groups of beneficiaries. Within Table $\mathrm{V}$ we propose a number of recommendations to help achieve a beneficial impact of future Cochrane overviews on evidence-based rehabilitation.

Cochrane Rehabilitation, which is aimed at acting as a "bridge" between authors and users, ${ }^{31}$ is well-placed to support the development of future overviews which are purposefully designed to generate impact, i.e. relevant, useful and used. Cochrane Rehabilitation may be able to facilitate and support input of key rehabilitation stakeholders internationally, ensuring representative contributions to key stages of the overview process. For example, with international networks of key stakeholders, Cochrane Rehabilitation could contribute to the development and sharing template "summaries" for different groups of beneficiaries which could be adapted and evolved as further lessons are learnt from new overviews. Further, the Cochrane Rehabilitation Methodology committee ${ }^{33,50}$ is ideally placed to support the development of consistent and high quality methods within rehabilitation overviews, promoting sharing of best practice between overview authors, and development of guidance and templates.

\section{CONCLUSION}

Cochrane overviews have the potential to play a key role in knowledge translation and therefore to have a beneficial impact on evidence based rehabilitation. Current Cochrane overviews of rehabilitation interventions commonly summarise evidence from a range of related systematic reviews, but sometimes fall short of presenting key findings in an easily accessible format and clearly sign-posting readers to relevant sources of evidence. To maximise the potential beneficial impact of future Cochrane overviews it is important that these address topics of importance to key beneficiaries, have clear pre-planned goals aimed at societal/economic as well as academic impact and clearly outline potential pathways to impact. A generic map was proposed to assist authors of Cochrane overviews in charting their intended pathways to impact, which can be further developed as experience accumulates. It is important that Cochrane 
overviews present summary information in a succinct and accessible format, and are maintained up-todate. In conclusion, high quality overviews addressing important rehabilitation topics, with carefully planned strategies to address impact goals, have the potential to have a beneficial impact on evidencebased rehabilitation, ultimately leading to improved rehabilitation outcomes. 


\section{REFERENCES}

1. Murad MH, Asi N, Alsawas M, Alahdab F. New evidence pyramid. Evid Based Med. 2016 Aug;21(4):125-7. PubMed PMID: 27339128. Pubmed Central PMCID: PMC4975798. Epub 2016/06/25.

2. Berlin JA, Golub RM. Meta-analysis as evidence: building a better pyramid. JAMA. 2014 Aug 13;312(6):603-5. PubMed PMID: 25117128. Epub 2014/08/15.

3. CEBM. Oxford Centre for Evidence-based Medicine - Levels of Evidence (March 2009). UK: Centre for Evidence-Based Medicine (CEBM); 2009 [cited 201921 January]; Available from:

https://www.cebm.net/2009/06/oxford-centre-evidence-based-medicine-levels-evidence-march-2009/. 4. Ioannidis JP. The Mass Production of Redundant, Misleading, and Conflicted Systematic Reviews and Meta-analyses. Milbank Q. 2016 Sep;94(3):485-514. PubMed PMID: 27620683. Pubmed Central PMCID: PMC5020151. Epub 2016/09/14.

5. Page MJ, Shamseer L, Altman DG, Tetzlaff J, Sampson M, Tricco AC, et al. Epidemiology and Reporting Characteristics of Systematic Reviews of Biomedical Research: A Cross-Sectional Study. PLoS Med. 2016 May;13(5):e1002028. PubMed PMID: 27218655. Pubmed Central PMCID: PMC4878797. Epub 2016/05/25.

6. Levack WM, Rathore FA, Pollet J, Negrini S. One in 11 Cochrane reviews are on rehabilitation interventions, according to pragmatic inclusion criteria developed by Cochrane Rehabilitation. Archives of Physical Medicine and Rehabilitation. 2019 (accepted). Epub 2019/03/02.

7. Bastian H, Glasziou P, Chalmers I. Seventy-five trials and eleven systematic reviews a day: how will we ever keep up? PLoS Med. 2010 Sep 21;7(9):e1000326. PubMed PMID: 20877712. Pubmed Central PMCID: PMC2943439. Epub 2010/09/30.

8. Moher D, Tetzlaff J, Tricco AC, Sampson M, Altman DG. Epidemiology and reporting characteristics of systematic reviews. PLoS Med. 2007 Mar 27;4(3):e78. PubMed PMID: 17388659. Pubmed Central PMCID: PMC1831728. Epub 2007/03/29.

9. Thomson D, Russell K, Becker L, Klassen T, Hartling L. The evolution of a new publication type: Steps and challenges of producing overviews of reviews. Res Synth Methods. $2010 \mathrm{Jul} ; 1(3-4): 198-211$. PubMed PMID: 26061466. Epub 2010/07/01.

10. Hartling L, Chisholm A, Thomson D, Dryden DM. A descriptive analysis of overviews of reviews published between 2000 and 2011. PLoS One. 2012;7(11):e49667. PubMed PMID: 23166744. Pubmed Central PMCID: PMC3499476. Epub 2012/11/21.

11. Hunt H, Pollock A, Campbell P, Estcourt L, Brunton G. An introduction to overviews of reviews: planning a relevant research question and objective for an overview. Syst Rev. 2018 Mar 1;7(1):39. PubMed PMID: 29490699. Pubmed Central PMCID: PMC5831229. Epub 2018/03/02.

12. Baker PR, Costello JT, Dobbins M, Waters EB. The benefits and challenges of conducting an overview of systematic reviews in public health: a focus on physical activity. J Public Health (Oxf). 2014 Sep;36(3):517-21. PubMed PMID: 25085438. Epub 2014/08/03.

13. Lunny C, McKenzie JE, McDonald S. Retrieval of overviews of systematic reviews in MEDLINE was improved by the development of an objectively derived and validated search strategy. J Clin Epidemiol. 2016 Jun;74:107-18. PubMed PMID: 26723872. Epub 2016/01/03.

14. Pollock M, Fernandes RM, Becker LA, Featherstone R, Hartling L. What guidance is available for researchers conducting overviews of reviews of healthcare interventions? A scoping review and qualitative metasummary. Syst Rev. 2016 Nov 14;5(1):190. PubMed PMID: 27842604. Pubmed Central PMCID: PMC5109841. Epub 2016/11/16.

15. Smith V, Devane D, Begley CM, Clarke M. Methodology in conducting a systematic review of systematic reviews of healthcare interventions. BMC Med Res Methodol. 2011 Feb 3;11(1):15. PubMed PMID: 21291558. Pubmed Central PMCID: PMC3039637. Epub 2011/02/05.

16. Lunny C, Brennan SE, McDonald S, McKenzie JE. Toward a comprehensive evidence map of overview of systematic review methods: paper 1-purpose, eligibility, search and data extraction. Syst Rev. 2017 Nov 21;6(1):231. PubMed PMID: 29162130. Pubmed Central PMCID: PMC5698938. Epub 2017/11/23. 17. McKenzie JE, Brennan SE. Overviews of systematic reviews: great promise, greater challenge. Syst Rev. 2017 Sep 8;6(1):185. PubMed PMID: 28886726. Pubmed Central PMCID: PMC5590122. Epub 2017/09/10. 
18. Becker L, Oxman A. Chapter 22: Overviews of reviews. In: Higgins JPT, Green S, editors. Cochrane Handbook for Systematic Reviews of Interventions v510: The Cochrane Collaboration; 2011.

19. Chen YF, Hemming K, Chilton PJ, Gupta KK, Altman DG, Lilford RJ. Scientific hypotheses can be tested by comparing the effects of one treatment over many diseases in a systematic review. J Clin Epidemiol. 2014 Dec;67(12):1309-19. PubMed PMID: 25282131. Epub 2014/10/06.

20. Cooper $\mathrm{H}$, Koenka AC. The overview of reviews: unique challenges and opportunities when research syntheses are the principal elements of new integrative scholarship. Am Psychol. 2012 Sep;67(6):446-62. PubMed PMID: 22352742. Epub 2012/02/23.

21. Pollock A, Campbell P, Brunton G, Hunt H, Estcourt L. Selecting and implementing overview methods: implications from five exemplar overviews. Syst Rev. 2017 Jul 18;6(1):145. PubMed PMID: 28720141. Pubmed Central PMCID: PMC5516331. Epub 2017/07/20.

22. Pieper D, Antoine SL, Morfeld JC, Mathes T, Eikermann M. Methodological approaches in conducting overviews: current state in HTA agencies. Res Synth Methods. 2014 Sep;5(3):187-99. PubMed PMID: 26052845. Epub 2015/06/09.

23. Lunny C, Brennan SE, McDonald S, McKenzie JE. Evidence map of studies evaluating methods for conducting, interpreting and reporting overviews of systematic reviews of interventions: rationale and design. Syst Rev. 2016 Jan 6;5:4. PubMed PMID: 26739283. Pubmed Central PMCID: PMC4702312. Epub 2016/01/08.

24. Worswick J, Wayne SC, Bennett R, Fiander M, Mayhew A, Weir MC, et al. Improving quality of care for persons with diabetes: an overview of systematic reviews - what does the evidence tell us? Syst Rev. 2013 May 7;2:26. PubMed PMID: 23647654. Pubmed Central PMCID: PMC3667096. Epub 2013/05/08. 25. Lunny C, Brennan SE, McDonald S, McKenzie JE. Toward a comprehensive evidence map of overview of systematic review methods: paper 2-risk of bias assessment; synthesis, presentation and summary of the findings; and assessment of the certainty of the evidence. Syst Rev. 2018 Oct 12;7(1):159. PubMed PMID: 30314530. Pubmed Central PMCID: PMC6186052. Epub 2018/10/14.

26. Ballard M, Montgomery P. Risk of bias in overviews of reviews: a scoping review of methodological guidance and four-item checklist. Res Synth Methods. 2017 Mar;8(1):92-108. PubMed PMID: 28074553. Epub 2017/01/12.

27. Thomson D, Foisy M, Oleszczuk M, Wingert A, Chisholm A, Hartling L. Overview of reviews in child health: evidence synthesis and the knowledge base for a specific population. Evid Based Child Health. 2013 Jan;8(1):3-10. PubMed PMID: 23878121. Epub 2013/07/24.

28. Pieper $D$, Buechter $R$, Jerinic $P$, Eikermann $M$. Overviews of reviews often have limited rigor: a systematic review. J Clin Epidemiol. 2012 Dec;65(12):1267-73. PubMed PMID: 22959594. Epub 2012/09/11. 29. Pollock M, Fernandes RM, Newton AS, Scott SD, Hartling L. A decision tool to help researchers make decisions about including systematic reviews in overviews of reviews of healthcare interventions. Syst Rev. 2019 Jan 22;8(1):29. PubMed PMID: 30670086. Epub 2019/01/24.

30. Brennan S, McKenzie JE, Middleton P, AkI EA, Green S, Reid J, et al., editors. Developing GRADE guidance for overviews of systematic reviews. Global Evidence Summit; 2017; Cape Town, SA: Cochrane Colloquium.

31. Negrini S, Gimigliano F, Arienti C, Kiekens C. Knowledge Translation: The Bridging Function of Cochrane Rehabilitation. Arch Phys Med Rehabil. 2018 Jun;99(6):1242-5. PubMed PMID: 29242131. Epub 2017/12/16.

32. UKRI. Pathways to impact. 2019 [cited 201924 January]; Available from: https://www.ukri.org/innovation/excellence-with-impact/pathways-to-impact/.

33. Negrini S, Arienti C, Gimigliano F, Grubisic F, Howe T, Ilieva E, et al. Cochrane Rehabilitation:

Organization and Functioning. Am J Phys Med Rehabil. 2018 Jan;97(1):68-71. PubMed PMID: 28953033. Epub 2017/09/28.

34. Moretti A, Gimigliano F, Arienti C, Pollet J, Kiekens C, Negrini S. The Cochrane Rehabilitation eBook: a knowledge translation tool to transfer evidence to different rehabilitation audiences. Eur J Phys Rehabil Med. 2018 Oct;54(5):808-10. PubMed PMID: 30220116. Epub 2018/09/18.

35. Reed MS. The Research Impact Handbook: Fast Track Impact; 2016.

36. WHO. Rehabilitation 2030: A Call for Action. World Health Organisation 2017. 
37. Caird J, Sutcliffe K, Kwan I, Dickson K, Thomas J. Mediating policy-relevant evidence at speed: are systematic reviews of systematic reviews a useful approach? . Evid Policy. 2015;11:81-97.

38. CDSR. Cochrane Database of Systematic Reviews (CDSR): Metrics. 2019 [cited 201924 January]; Available from: https://community.cochrane.org/editorial-and-publishing-policy-resource/overviewcochrane-library-and-related-content/databases-included-cochrane-library/cochrane-database-systematicreviews-cdsr.

39. Pollock A, Farmer SE, Brady MC, Langhorne P, Mead GE, Mehrholz J, et al. Interventions for improving upper limb function after stroke. Cochrane Database Syst Rev. 2014 Nov 12(11):CD010820. PubMed PMID: 25387001. Epub 2014/11/12.

40. REF. Research Excellence Framework 2014: Panel Criteria and working methods. UK: 2012.

41. Anderson L, Taylor RS. Cardiac rehabilitation for people with heart disease: an overview of Cochrane systematic reviews. Cochrane Database Syst Rev. 2014 Dec 12(12):CD011273. PubMed PMID: 25503364. Epub 2014/12/17.

42. Geneen L, Moore RA, Clarke C, Martin D, Colvin LA, Smith BH. Physical activity and exercise for chronic pain in adults: an overview of Cochrane Reviews. Cochrane Database Syst Rev. $2017 \mathrm{Apr}$ 24;4:CD011279. PubMed PMID: 28436583. Pubmed Central PMCID: PMC5461882. Epub 2017/04/25.

43. Welsh EJ, Evans DJ, Fowler SJ, Spencer S. Interventions for bronchiectasis: an overview of Cochrane systematic reviews. Cochrane Database Syst Rev. 2015 Jul 14(7):CD010337. PubMed PMID: 26171905. Epub 2015/07/15.

44. O'Connell NE, Wand BM, McAuley J, Marston L, Moseley GL. Interventions for treating pain and disability in adults with complex regional pain syndrome. Cochrane Database Syst Rev. $2013 \mathrm{Apr}$ 30(4):CD009416. PubMed PMID: 23633371. Epub 2013/05/02.

45. Ng L, Khan F, Young CA, Galea M. Symptomatic treatments for amyotrophic lateral sclerosis/motor neuron disease. Cochrane Database Syst Rev. 2017 Jan 10;1:CD011776. PubMed PMID: 28072907. Epub 2017/01/11.

46. Oaklander AL, Lunn MP, Hughes RA, van Schaik IN, Frost C, Chalk CH. Treatments for chronic inflammatory demyelinating polyradiculoneuropathy (CIDP): an overview of systematic reviews. Cochrane Database Syst Rev. 2017 Jan 13;1:CD010369. PubMed PMID: 28084646. Pubmed Central PMCID: PMC5468847. Epub 2017/01/14.

47. RCP. National clinical guideline for stroke. London: Royal College of Physicians, 2016.

48. Elliott JH, Synnot A, Turner T, Simmonds M, Akl EA, McDonald S, et al. Living systematic review: 1. Introduction-the why, what, when, and how. J Clin Epidemiol. 2017 Nov;91:23-30. PubMed PMID: 28912002. Epub 2017/09/16.

49. Pollock A, Campbell P, Struthers C, Synnot A, Nunn J, Hill S, et al. Stakeholder involvement in systematic reviews: a scoping review. Syst Rev. 2018 Nov 24;7(1):208. PubMed PMID: 30474560. Pubmed Central PMCID: PMC6260873. Epub 2018/11/27.

50. Levack WM, Meyer T, Negrini S, Malmivaara A. Cochrane Rehabilitation Methodology Committee: an international survey of priorities for future work. Eur J Phys Rehabil Med. 2017 Oct;53(5):814-7. PubMed PMID: 29110449. Epub 2017/11/08. 


\section{NOTES}

Conflict of interest: None known

Acknowledgement: Pauline Campbell for assisting with the referencing within the manuscript. Royal Society Te Apārangi, New Zealand, for financial support to host the meeting leading to this paper.

\section{TABLES, FIGURES \& SUPPLEMENTARY MATERIAL}

\section{$\underline{\text { TABLES }}$}

Table I: Characteristics of included overviews

Table II: Summary of results of included overviews

Table III: Summary of impact of included overviews

Table IV: Summary of key access data for the included overviews

Table V: Recommendations for future overviews

\section{FIGURES}

Figure 1: PRISMA diagram, showing search results

Figure 2: Proposed map of potential pathways to impact for Cochrane overviews in the field of rehabilitation

\section{SUPPLEMENTARY DIGITAL MATERIAL}

Appendix 1: Table of excluded overviews

Appendix 2: Summary of outputs from worked example, extracted from ResearchFish database (last updated March 2018)

Appendix 3: Examples of "clusters" of Cochrane reviews which could be brought together in an overview 


\begin{tabular}{|c|c|c|c|c|c|c|c|}
\hline Overview title & $\begin{array}{l}\text { Interventions } \\
\text { for improving } \\
\text { upper limb } \\
\text { function after } \\
\text { stroke }^{39}\end{array}$ & $\begin{array}{l}\text { Cardiac rehabilitation } \\
\text { for people with heart } \\
\text { disease }^{41}\end{array}$ & $\begin{array}{l}\text { Physical activity } \\
\& \text { exercise for } \\
\text { chronic pain in } \\
\text { adults }^{42}\end{array}$ & $\begin{array}{l}\text { Interventions for } \\
\text { bronchiectasis }^{43}\end{array}$ & $\begin{array}{l}\text { Interventions for } \\
\text { treating pain and } \\
\text { disability in adults } \\
\text { with complex } \\
\text { regional pain } \\
\text { syndrome }^{44}\end{array}$ & $\begin{array}{l}\text { Symptomatic } \\
\text { treatments for } \\
\text { amyotrophic } \\
\text { lateral sclerosis/ } \\
\text { motor neuron } \\
\text { disease (MND) } \\
\end{array}$ & $\begin{array}{l}\text { Treatments for chronic } \\
\text { inflammatory } \\
\text { demyelinating } \\
\text { polyradiculoneur-opathy } \\
(\text { CIDP) }\end{array}$ \\
\hline $\begin{array}{l}\text { Stated aim / question } \\
\text { of overview }\end{array}$ & $\begin{array}{l}\text { To synthesise } \\
\text { systematic } \\
\text { reviews of } \\
\text { interventions to } \\
\text { improve upper } \\
\text { limb function } \\
\text { after stroke. }\end{array}$ & $\begin{array}{l}\text { To conduct an } \\
\text { overview of Cochrane } \\
\text { systematic reviews to } \\
\text { provide a } \\
\text { contemporary review } \\
\text { of the evidence for } \\
\text { delivery of cardiac } \\
\text { rehabilitation, to } \\
\text { identify opportunities } \\
\text { for merging or } \\
\text { splitting existing } \\
\text { Cochrane reviews, } \\
\text { and to identify } \\
\text { current evidence gaps } \\
\text { to inform new cardiac } \\
\text { rehabilitation } \\
\text { systematic review } \\
\text { titles. }\end{array}$ & $\begin{array}{l}\text { To determine (1) } \\
\text { the effectiveness } \\
\text { of different } \\
\text { physical activity } \\
\text { and exercise } \\
\text { interventions in } \\
\text { reducing pain } \\
\text { severity and its } \\
\text { impact on } \\
\text { function, quality } \\
\text { of life, and } \\
\text { healthcare use; } \\
\text { and (2) the } \\
\text { evidence for any } \\
\text { adverse effects or } \\
\text { harm associated } \\
\text { with physical } \\
\text { activity and } \\
\text { exercise } \\
\text { interventions. }\end{array}$ & $\begin{array}{l}\text { To provide an overview } \\
\text { of the efficacy and } \\
\text { safety of interventions } \\
\text { for adults and children } \\
\text { with bronchiectasis } \\
\text { from Cochrane reviews. } \\
\text { To identify gaps in the } \\
\text { evidence base that will } \\
\text { inform } \\
\text { recommendations for } \\
\text { new research and } \\
\text { reviews, and } \\
\text { To summarise } \\
\text { information on } \\
\text { reported outcomes and } \\
\text { make } \\
\text { recommendations for } \\
\text { the reporting of } \\
\text { standard outcomes in } \\
\text { future trials and } \\
\text { reviews. }\end{array}$ & $\begin{array}{l}\text { To provide an } \\
\text { overview of } \\
\text { evidence from } \\
\text { systematic reviews } \\
\text { to determine the } \\
\text { efficacy of any } \\
\text { intervention used } \\
\text { to reduce pain, } \\
\text { disability or both in } \\
\text { adults with complex } \\
\text { regional pain } \\
\text { syndrome, and to } \\
\text { direct readers to } \\
\text { these reviews. }\end{array}$ & $\begin{array}{l}\text { To summarise the } \\
\text { evidence from } \\
\text { Cochrane } \\
\text { Systematic } \\
\text { Reviews of all } \\
\text { symptomatic } \\
\text { treatments for } \\
\text { MND. }\end{array}$ & $\begin{array}{l}\text { To summarise the evidence } \\
\text { from Cochrane systematic } \\
\text { reviews and non-Cochrane } \\
\text { systematic reviews of any } \\
\text { treatment for CIDP and to } \\
\text { compare the effects of } \\
\text { treatments. }\end{array}$ \\
\hline $\begin{array}{l}\text { Inclusion criteria: } \\
\text { participants }\end{array}$ & $\begin{array}{l}\text { Adults with } \\
\text { stroke }\end{array}$ & $\begin{array}{l}\text { Adults with heart } \\
\text { disease }\end{array}$ & $\begin{array}{l}\text { Adults reporting } \\
\text { chronic non- } \\
\text { cancer pain (for at } \\
\text { least } 3 \text { months) }\end{array}$ & $\begin{array}{l}\text { Adults and children } \\
\text { with non-cystic fibrosis } \\
\text { bronchiectasis }\end{array}$ & $\begin{array}{l}\text { Adults with chronic } \\
\text { regional pain } \\
\text { syndrome or an } \\
\text { alternative } \\
\text { descriptor for this } \\
\text { condition }\end{array}$ & People with MND & $\begin{array}{l}\text { People with CIDP (or } \\
\text { reviews where }>95 \% \text { of } \\
\text { participants have CIDP) }\end{array}$ \\
\hline $\begin{array}{l}\text { Inclusion criteria: } \\
\text { interventions }\end{array}$ & $\begin{array}{l}\text { Any focussed on } \\
\text { improving } \\
\text { upper limb } \\
\text { function }\end{array}$ & Cardiac rehabilitation & $\begin{array}{l}\text { Physical activity } \\
\text { or exercise as a } \\
\text { stand-alone } \\
\text { intervention }\end{array}$ & Any & $\begin{array}{l}\text { Any focussed on } \\
\text { reducing pain and/ } \\
\text { or disability }\end{array}$ & $\begin{array}{l}\text { Any non-disease } \\
\text { modifying and } \\
\text { symptomatic } \\
\text { intervention } \\
\end{array}$ & $\begin{array}{l}\text { Any intervention for CIDP, } \\
\text { including treatments of } \\
\text { underlying disease and } \\
\text { treatment of symptoms }\end{array}$ \\
\hline $\begin{array}{l}\text { Inclusion criteria: } \\
\text { outcomes }\end{array}$ & $\begin{array}{l}\text { - Upper limb } \\
\text { function } \\
\text { - Upper limb } \\
\text { impairment }\end{array}$ & $\begin{array}{l}\text { - Mortality } \\
\text { - Morbidity } \\
\text { - Myocardial } \\
\text { infarction } \\
\text { - Revascularisations }\end{array}$ & $\begin{array}{l}\text { - Self reported } \\
\text { pain; } \\
\text { - Physical } \\
\text { function, }\end{array}$ & $\begin{array}{l}\text { - Exacerbations } \\
\text { - Lung function, } \\
\text { - Quality of life; } \\
\text { - Symptoms, }\end{array}$ & $\begin{array}{l}\text { - Pain, } \\
\text { - Disability, } \\
\text { - Adverse events; } \\
\text { - Quality of life, }\end{array}$ & $\begin{array}{l}\text { Outcomes as } \\
\text { reported in } \\
\text { individual } \\
\text { Cochrane } \\
\text { reviews: }\end{array}$ & $\begin{array}{l}\text { Outcomes as reported in } \\
\text { individual systematic } \\
\text { reviews: } \\
\text { - Change in disability } \\
\text { - Impairment }\end{array}$ \\
\hline
\end{tabular}




\begin{tabular}{|c|c|c|c|c|c|c|c|}
\hline & $\begin{array}{l}\text { - Activities of } \\
\text { daily living } \\
\text { - other } \\
\text { outcomes } \\
\text { reported in } \\
\text { included } \\
\text { reviews, } \\
\text { including } \\
\text { measures of } \\
\text { participation, } \\
\text { mood, adverse } \\
\text { events and } \\
\text { quality of life }\end{array}$ & $\begin{array}{l}\text { - Hospitalisations, } \\
\text { - Health-related } \\
\text { quality of life } \\
\text { - Adverse events } \\
\text { - Adherence to } \\
\text { cardiac rehab; } \\
\text { - Costs \& cost- } \\
\text { effectiveness }\end{array}$ & $\begin{array}{l}\text { - Psychological } \\
\text { function, } \\
\text { - Quality of life, } \\
\text { - Adherence, } \\
\text { - Healthcare use, } \\
\text { - Adverse } \\
\text { events, } \\
\text { - Death }\end{array}$ & $\begin{array}{l}\text { - Sputum } \\
\text { characteristics, } \\
\text { - Adverse events, } \\
\text { - Hospitalisation, } \\
\text { - Mortality. }\end{array}$ & $\begin{array}{l}\text { - Emotional well } \\
\text { being, } \\
\text { - Participant } \\
\text { ratings of } \\
\text { improvement or } \\
\text { satisfaction }\end{array}$ & $\begin{array}{l}\text { - Quality of life } \\
\text { and health status } \\
\text { - Impairment } \\
\text { - Disability or } \\
\text { limitation in } \\
\text { activity } \\
\text { - Participation } \\
\text { - Survival } \\
\text { - Hospitalisation } \\
\text { - Cost- } \\
\text { effectiveness } \\
\text { - Adverse events }\end{array}$ & $\begin{array}{l}\text { - Quality of life } \\
\text { - Adverse events } \\
\text { - Costs }\end{array}$ \\
\hline $\begin{array}{l}\text { Inclusion criteria: type } \\
\text { of study }\end{array}$ & $\begin{array}{l}\text { Cochrane } \\
\text { reviews and } \\
\text { non-Cochrane } \\
\text { reviews (of } \\
\text { RCTs) }\end{array}$ & Cochrane reviews & Cochrane reviews & $\begin{array}{l}\text { Cochrane reviews. RCTs } \\
\text { and CCTs }\end{array}$ & $\begin{array}{l}\text { Cochrane reviews } \\
\text { and non-Cochrane } \\
\text { reviews }\end{array}$ & Cochrane reviews & $\begin{array}{l}\text { Cochrane reviews and non- } \\
\text { Cochrane reviews. RCTs not } \\
\text { included in Cochrane } \\
\text { reviews. }\end{array}$ \\
\hline Search strategy & $\begin{array}{l}\text { CDSR, DARE, } \\
\text { PROSPERO. }\end{array}$ & CDSR & CDSR & $\begin{array}{l}\text { CDSR. Cochrane } \\
\text { Airways Group trials } \\
\text { register. }\end{array}$ & $\begin{array}{l}\text { MEDLINE, Embase, } \\
\text { CDSR, CINAHL, } \\
\text { PEDro, LILACS }\end{array}$ & CDSR & $\begin{array}{l}\text { CDSR, DARE, MEDLINE, } \\
\text { Embase, CINAHL. }\end{array}$ \\
\hline $\begin{array}{l}\text { Updating searches of } \\
\text { out of date reviews to } \\
\text { identify new trials? }\end{array}$ & No updating & No updating & No updating & $\begin{array}{l}\text { Yes - trials not included } \\
\text { in reviews were } \\
\text { identified and included } \\
\text { in the overview. } \\
\text { (However trials were } \\
\text { not incorporated in } \\
\text { Cochrane reviews, as } \\
\text { had been planned) }\end{array}$ & $\begin{array}{l}\text { No searching for } \\
\text { trials, but sought } \\
\text { more up to date } \\
\text { non-Cochrane } \\
\text { reviews where a } \\
\text { Cochrane review } \\
\text { was out of date. }\end{array}$ & No updating & $\begin{array}{l}\text { Yes - searched for RCTs of } \\
\text { treatment of fatigue or pain } \\
\text { in CIPD, from Cochrane } \\
\text { Neuromuscular Specialised } \\
\text { Register, Cochrane Central } \\
\text { Register of } \\
\text { Controlled Trials, MEDLINE, } \\
\text { Embase, CINAHL. }\end{array}$ \\
\hline $\begin{array}{l}\text { Selection of reviews } \\
\text { (methods) }\end{array}$ & $\begin{array}{l}\text { Two authors } \\
\text { independently } \\
\text { apply inclusion } \\
\text { criteria }\end{array}$ & $\begin{array}{l}\text { Two authors } \\
\text { independently apply } \\
\text { inclusion criteria }\end{array}$ & $\begin{array}{l}\text { Two authors } \\
\text { independently } \\
\text { apply inclusion } \\
\text { criteria }\end{array}$ & $\begin{array}{l}\text { Two authors } \\
\text { independently apply } \\
\text { inclusion criteria for } \\
\text { Cochrane reviews (only } \\
\text { one author for trials). }\end{array}$ & $\begin{array}{l}\text { Two authors } \\
\text { independently } \\
\text { apply inclusion } \\
\text { criteria }\end{array}$ & $\begin{array}{l}\text { Two authors } \\
\text { independently } \\
\text { apply inclusion } \\
\text { criteria }\end{array}$ & $\begin{array}{l}\text { Two authors independently } \\
\text { apply inclusion criteria }\end{array}$ \\
\hline $\begin{array}{l}\text { Data extraction (what } \\
\text { was extracted/ } \\
\text { reported?) }\end{array}$ & $\begin{array}{l}\text { Characteristics } \\
\text { of reviews; } \\
\text { results of all } \\
\text { relevant meta- } \\
\text { analyses }\end{array}$ & $\begin{array}{l}\text { Characteristics of } \\
\text { reviews; } \\
\text { characteristics of } \\
\text { included RCTs; results } \\
\text { of meta-analyses } \\
\end{array}$ & $\begin{array}{l}\text { Characteristics of } \\
\text { reviews; results of } \\
\text { meta-analyses }\end{array}$ & $\begin{array}{l}\text { Characteristics of } \\
\text { reviews; results of } \\
\text { meta-analyses }\end{array}$ & $\begin{array}{l}\text { Characteristics of } \\
\text { reviews; results of } \\
\text { meta-analyses }\end{array}$ & $\begin{array}{l}\text { Characteristics of } \\
\text { reviews; narrative } \\
\text { account of } \\
\text { results. }\end{array}$ & $\begin{array}{l}\text { Trials included within } \\
\text { reviews. Narrative account } \\
\text { of trial results. }\end{array}$ \\
\hline $\begin{array}{l}\text { Assessment of quality } \\
\text { of reviews (Tool or } \\
\text { method) }\end{array}$ & $\begin{array}{l}\text { Modified } \\
\text { AMSTAR }\end{array}$ & Revised AMSTAR & AMSTAR & AMSTAR & AMSTAR & AMSTAR & AMSTAR \\
\hline
\end{tabular}




\begin{tabular}{|l|l|l|l|l|l|l|}
$\begin{array}{l}\text { Assessment of quality } \\
\text { of evidence within } \\
\text { reviews (approach or } \\
\text { method, e.g. GRADE) }\end{array}$ & $\begin{array}{l}\text { GRADE } \\
\text { approach, (with } \\
\text { use of } \\
\text { algorithm) }\end{array}$ & GRADE approach & $\begin{array}{l}\text { Quality of } \\
\text { evidence grouped } \\
\text { according to } \\
\text { tiers" (based on } \\
\text { explicit criteria) }\end{array}$ & GRADE approach & $\begin{array}{l}\text { GRADE approach. } \\
\text { (with explicit } \\
\text { criteria for } \\
\text { downgrading). }\end{array}$ & $\begin{array}{l}\text { GRADE approach } \\
\text { GRADE approach }\end{array}$ \\
\hline
\end{tabular}

Table I: Characteristics of included overviews 


\begin{tabular}{|c|c|c|c|c|c|c|c|}
\hline Overview title & $\begin{array}{l}\text { Interventions } \\
\text { for improving } \\
\text { upper limb } \\
\text { function after } \\
\text { stroke }^{39}\end{array}$ & $\begin{array}{l}\text { Cardiac } \\
\text { rehabilitation } \\
\text { for people } \\
\text { with heart } \\
\text { disease }^{41}\end{array}$ & $\begin{array}{l}\text { Physical } \\
\text { activity \& } \\
\text { exercise for } \\
\text { chronic pain } \\
\text { in adults }{ }^{42}\end{array}$ & $\begin{array}{l}\text { Interventions for } \\
\text { bronchiectasis }^{43}\end{array}$ & $\begin{array}{l}\text { Interventions for treating pain } \\
\text { and disability in adults with } \\
\text { complex regional pain } \\
\text { syndrome }^{44}\end{array}$ & $\begin{array}{l}\text { Symptomatic treatments for } \\
\text { amyotrophic lateral } \\
\text { sclerosis/motor neuron } \\
\text { disease (MND) }\end{array}$ & $\begin{array}{l}\text { Treatments for chronic } \\
\text { inflammatory } \\
\text { demyelinating } \\
\text { polyradiculoneuropathy } \\
\text { (CIDP) }\end{array}$ \\
\hline $\begin{array}{l}\text { Number of reviews } \\
\text { included }\end{array}$ & 40 & 6 & 21 & 21 & 19 & 9 & 5 \\
\hline $\begin{array}{l}\text { Number of } \\
\text { included reviews } \\
\text { which are relevant } \\
\text { to rehabilitation }\end{array}$ & 40 & 6 & 21 & $\begin{array}{l}4 / 21 \text { reviews of } \\
\text { non- } \\
\text { pharmacological } \\
\text { interventions }\end{array}$ & $\begin{array}{l}3 / 19 \text { reviews categorised as } \\
\text { "Physical and rehabilitation } \\
\text { interventions"; } 1 / 19 \text { reviews } \\
\text { "autogenic relaxation training" }\end{array}$ & $\begin{array}{l}3 / 9 \text { focused on } \\
\text { pharmacological } \\
\text { interventions; } 3 / 9 \text { focused on } \\
\text { rehabilitation; } 3 / 9 \text { focused on } \\
\text { general / multidisciplinary } \\
\text { care }\end{array}$ & 0 \\
\hline $\begin{array}{l}\text { Number of reviews } \\
\text { with data extracted }\end{array}$ & 40 & 6 & 21 & $\begin{array}{l}9 \text { (only } 9 / 21 \\
\text { reported results for } \\
\text { participants with } \\
\text { bronchiectasis } \\
\text { alone) }\end{array}$ & 19 & 6 (3 were 'empty' reviews) & $\begin{array}{l}\text { Data were extracted from } \\
15 \text { RCTs identified from } \\
\text { the } 5 \text { reviews }\end{array}$ \\
\hline $\begin{array}{c}\text { of which Cochrane } \\
\text { reviews }\end{array}$ & 19 & 6 & 21 & 9 & 6 & 6 & 5 \\
\hline $\begin{array}{c}\text { of which Non- } \\
\text { Cochrane reviews }\end{array}$ & 21 & 0 & 0 & 0 & 13 & 0 & 0 \\
\hline $\begin{array}{l}\text { Number of RCTs } \\
\text { included, which } \\
\text { were not in the } \\
\text { included reviews }\end{array}$ & 0 & 0 & 0 & $\begin{array}{l}0 \text { (further } 46 \text { RCTs } \\
\text { which were not } \\
\text { included in reviews } \\
\text { were identified, but } \\
\text { not 'included') }\end{array}$ & 0 & 0 & $\begin{array}{l}0 \text { (further } 8 \text { RCTs which } \\
\text { were not included in } \\
\text { reviews were identified; } \\
\text { these were not 'included' } \\
\text { in the overview, but } \\
\text { listed and described in } \\
\text { discussion) }\end{array}$ \\
\hline $\begin{array}{l}\text { Number of RCTs } \\
\text { within the included } \\
\text { reviews }\end{array}$ & 503 & 148 & 381 & $\begin{array}{l}\text { total } 40 \text { (range 1- } \\
11 \text {, per individual } \\
\text { RCT) }\end{array}$ & listed in table (not totalled) & listed in table (not totalled) & 15 \\
\hline $\begin{array}{l}\text { Number of } \\
\text { participants in RCTs } \\
\text { within the included } \\
\text { reviews }\end{array}$ & 18078 & 98093 & 37143 & $\begin{array}{l}\text { range } 40-1040 \\
\text { (per individual } \mathrm{RCT} \text { ) }\end{array}$ & listed in table (not totalled) & listed in table (not totalled) & $\begin{array}{l}\text { Stated for individual trials } \\
\text { within text (not totalled) }\end{array}$ \\
\hline
\end{tabular}

\section{Table II: Summary of results of included overviews}

RCT: Randomised controlled trial 


\begin{tabular}{|c|c|c|c|c|c|c|c|}
\hline $\begin{array}{l}\text { Summary of } \\
\text { impact }\end{array}$ & $\begin{array}{l}\text { Interventions for } \\
\text { improving upper limb } \\
\text { function after stroke } 39\end{array}$ & $\begin{array}{l}\text { Cardiac rehabilitation } \\
\text { for people with heart } \\
\text { disease }^{41}\end{array}$ & $\begin{array}{l}\text { Physical activity \& exercise } \\
\text { for chronic pain in adults }{ }^{42}\end{array}$ & $\begin{array}{l}\text { Interventions for } \\
\text { bronchiectasis }^{43}\end{array}$ & $\begin{array}{l}\text { Interventions for } \\
\text { treating pain and } \\
\text { disability in adults with } \\
\text { complex regional pain } \\
\text { syndrome }^{44}\end{array}$ & $\begin{array}{l}\text { Symptomatic } \\
\text { treatments for } \\
\text { amyotrophic } \\
\text { lateral } \\
\text { sclerosis/motor } \\
\text { neuron disease } \\
\text { (MND) } 45\end{array}$ & $\begin{array}{l}\text { Treatments for } \\
\text { chronic } \\
\text { inflammatory } \\
\text { demyelinating } \\
\text { polyradiculoneuro } \\
\text { pathy (CIDP) }\end{array}$ \\
\hline $\begin{array}{l}\text { What is the } \\
\text { intended } \\
\text { purpose of the } \\
\text { overview, } \\
\text { relating to } \\
\text { impact on } \\
\text { rehabilitation } \\
\text { practice? }\end{array}$ & $\begin{array}{l}\text { To synthesise relevant } \\
\text { evidence into a single } \\
\text { accessible, } \\
\text { comprehensive } \\
\text { document that brings } \\
\text { together all relevant } \\
\text { reviews, signposting } \\
\text { others (including } \\
\text { clinicians and policy } \\
\text { makers) toward relevant } \\
\text { systematic reviews, } \\
\text { thereby supporting them } \\
\text { in decision making for } \\
\text { rehabilitation. }\end{array}$ & $\begin{array}{l}\text { To conduct an overview } \\
\text { of Cochrane systematic } \\
\text { reviews to provide a } \\
\text { contemporary review of } \\
\text { the evidence for } \\
\text { delivery of the } \\
\text { intervention. }\end{array}$ & $\begin{array}{l}\text { To bring together all } \\
\text { relevant published } \\
\text { information to evaluate the } \\
\text { current evidence on effects } \\
\text { and adverse effects, and } \\
\text { identify the availability and } \\
\text { quality of evidence-based } \\
\text { interventions. } \\
\text { To determine the extent to } \\
\text { which the published } \\
\text { systematic reviews have } \\
\text { accurately assessed the } \\
\text { evidence, which will help to } \\
\text { direct future guidelines. }\end{array}$ & $\begin{array}{l}\text { To document the } \\
\text { evidence for the efficacy, } \\
\text { safety and tolerability of } \\
\text { the range of interventions } \\
\text { covered by the reviews. }\end{array}$ & $\begin{array}{l}\text { To systematically } \\
\text { compile and summarise } \\
\text { the evidence of the } \\
\text { effectiveness and } \\
\text { potential harm of } \\
\text { different interventions } \\
\text { for the same condition } \\
\text { into one accessible and } \\
\text { usable document, } \\
\text { and to direct readers to } \\
\text { the sources of } \\
\text { evidence. }\end{array}$ & $\begin{array}{l}\text { To give } \\
\text { clinicians, policy } \\
\text { makers and } \\
\text { informed } \\
\text { consumers an } \\
\text { accessible } \\
\text { overview of } \\
\text { information } \\
\text { from a wide } \\
\text { range of } \\
\text { reviews. }\end{array}$ & $\begin{array}{l}\text { Drawing reviews } \\
\text { together } \\
\text { makes their } \\
\text { combined } \\
\text { information more } \\
\text { accessible to } \\
\text { people with } \\
\text { the condition, } \\
\text { healthcare } \\
\text { professionals, and } \\
\text { researchers. }\end{array}$ \\
\hline $\begin{array}{l}\text { What is the } \\
\text { intended } \\
\text { purpose of the } \\
\text { overview, } \\
\text { relating to } \\
\text { impact on } \\
\text { research? }\end{array}$ & $\begin{array}{l}\text { To be able to make } \\
\text { specific } \\
\text { recommendations for } \\
\text { future research. }\end{array}$ & $\begin{array}{l}\text { To identify } \\
\text { opportunities for } \\
\text { merging or splitting } \\
\text { existing Cochrane } \\
\text { reviews, and to identify } \\
\text { current evidence gaps } \\
\text { to inform new } \\
\text { systematic review titles. }\end{array}$ & $\begin{array}{l}\text { To determine the extent to } \\
\text { which the published } \\
\text { systematic reviews have } \\
\text { accurately assessed the } \\
\text { evidence, which will } \\
\text { identify current research } \\
\text { gaps. }\end{array}$ & $\begin{array}{l}\text { To identify gaps in the } \\
\text { evidence base to inform } \\
\text { recommendations for } \\
\text { new research and } \\
\text { reviews. } \\
\text { To summarise } \\
\text { information } \\
\text { on reported outcomes } \\
\text { and make } \\
\text { recommendations for the } \\
\text { reporting of standard } \\
\text { outcomes in future trials } \\
\text { and reviews. }\end{array}$ & Not stated explicitly & $\begin{array}{l}\text { To highlight } \\
\text { areas for } \\
\text { further } \\
\text { research. }\end{array}$ & $\begin{array}{l}\text { Drawing reviews } \\
\text { together } \\
\text { makes their } \\
\text { combined } \\
\text { information more } \\
\text { accessible to } \\
\text { researchers, and } \\
\text { enables topics } \\
\text { for future } \\
\text { research to be } \\
\text { identified. }\end{array}$ \\
\hline $\begin{array}{l}\text { In what way is } \\
\text { the included } \\
\text { evidence } \\
\text { "mapped"/ } \\
\text { "signposted" } \\
\text { (i.e. how is } \\
\text { evidence } \\
\text { summarised to } \\
\text { direct the }\end{array}$ & $\begin{array}{l}\text { A figure lists each } \\
\text { intervention, the quality } \\
\text { of the underpinning } \\
\text { evidence and key } \\
\text { findings. } \\
\text { Tables summarise } \\
\text { interventions and } \\
\text { outcomes, reviews } \\
\text { relevant to each }\end{array}$ & $\begin{array}{l}\text { A table summarises } \\
\text { interventions and } \\
\text { outcomes, and quality } \\
\text { of evidence (GRADE). } \\
\text { A table summarises } \\
\text { outcomes from the } \\
\text { included reviews, the } \\
\text { quality of the reviews } \\
\text { and of the evidence. }\end{array}$ & $\begin{array}{l}\text { A table provides } \\
\text { information with key } \\
\text { characteristics of each } \\
\text { review and an overall } \\
\text { statement about each } \\
\text { outcome, adherence and } \\
\text { adverse effects. }\end{array}$ & $\begin{array}{l}\text { A table presents an } \\
\text { overview of the relevant } \\
\text { evidence (including } \\
\text { potential new studies) in } \\
\text { Cochrane reviews, trials } \\
\text { and guideline } \\
\text { recommendations, } \\
\text { together with } \\
\text { recommendations for }\end{array}$ & $\begin{array}{l}\text { A table provides a list of } \\
\text { reviews and trials, and } \\
\text { interventions to which } \\
\text { they relate. } \\
\text { A table synthesises } \\
\text { interventions, } \\
\text { outcomes and quality } \\
\text { of evidence (GRADE). }\end{array}$ & $\begin{array}{l}\text { A table provides } \\
\text { a list of reviews, } \\
\text { including } \\
\text { interventions } \\
\text { and outcomes, } \\
\text { and quality of } \\
\text { evidence } \\
\text { (GRADE). }\end{array}$ & $\begin{array}{l}\text { A table provides a } \\
\text { list of RCTs, } \\
\text { including } \\
\text { interventions and } \\
\text { comparisons, with } \\
\text { their references, } \\
\text { as well as trials in } \\
\text { progress. }\end{array}$ \\
\hline
\end{tabular}




\begin{tabular}{|c|c|c|c|c|c|c|c|}
\hline $\begin{array}{l}\text { reader to more } \\
\text { detailed } \\
\text { material in } \\
\text { systematic } \\
\text { reviews or } \\
\text { primary } \\
\text { research)? }\end{array}$ & $\begin{array}{l}\text { intervention, effect sizes } \\
\text { for comparisons on the } \\
\text { identified outcome } \\
\text { measures and quality of } \\
\text { evidence (GRADE). } \\
\text { A table lists all relevant } \\
\text { interventions as } \\
\text { identified by a } \\
\text { stakeholder group, and } \\
\text { then maps all identified } \\
\text { reviews and ongoing } \\
\text { reviews. }\end{array}$ & & & $\begin{array}{l}\text { Cochrane reviews and } \\
\text { research priorities. } \\
\text { Tables list interventions, } \\
\text { outcomes and } \\
\text { interpretation of } \\
\text { outcomes. }\end{array}$ & & & \\
\hline $\begin{array}{l}\text { What are the } \\
\text { implications of } \\
\text { the findings for } \\
\text { rehabilitation } \\
\text { practice? }\end{array}$ & $\begin{array}{l}\text { The quality of the } \\
\text { evidence base is } \\
\text { summarised. } \\
\text { Interventions supported } \\
\text { by moderate-quality } \\
\text { GRADE evidence are } \\
\text { identified. These are } \\
\text { recommended for } \\
\text { consideration in practice, } \\
\text { provided that } \\
\text { practitioners use expert } \\
\text { reasoning and judgement } \\
\text { skills when interpreting } \\
\text { and applying the } \\
\text { evidence to individual } \\
\text { cases in specific settings. } \\
\text { Implications for } \\
\text { interventions that are } \\
\text { currently used routinely } \\
\text { in practice, but where } \\
\text { there is insufficient } \\
\text { evidence, and for new } \\
\text { interventions supported } \\
\text { by emerging evidence are } \\
\text { stated. }\end{array}$ & $\begin{array}{l}\text { The evidence compiled } \\
\text { by this overview } \\
\text { supports current } \\
\text { international clinical } \\
\text { guidelines on the } \\
\text { intervention. }\end{array}$ & $\begin{array}{l}\text { Table with conclusions by } \\
\text { review authors and } \\
\text { conclusions by overview } \\
\text { authors (who assessed the } \\
\text { review authors' } \\
\text { interpretations). } \\
\text { - Implications for } \\
\text { clinicians and people with } \\
\text { the condition: the } \\
\text { overview highlights } \\
\text { inconsistent results and } \\
\text { low quality evidence. } \\
\text { Adverse effects seemed } \\
\text { minimal and transient. } \\
\text { Implications for policy } \\
\text { makers: this overview } \\
\text { demonstrates variable } \\
\text { benefits with minimal } \\
\text { adverse effects of the } \\
\text { intervention, but evidence } \\
\text { was of low quality. Based } \\
\text { on this overview, no } \\
\text { evidence-based guidance } \\
\text { can be provided re. the } \\
\text { content of the intervention. }\end{array}$ & $\begin{array}{l}\text { Key findings / } \\
\text { implications for practice } \\
\text { from the overview in } \\
\text { terms of the major } \\
\text { outcomes that authors } \\
\text { felt were most important } \\
\text { in people with the } \\
\text { condition are } \\
\text { summarised. }\end{array}$ & $\begin{array}{l}\text { The overview states } \\
\text { that, until further larger } \\
\text { trials are undertaken, } \\
\text { an evidence-based } \\
\text { approach to managing } \\
\text { the condition will } \\
\text { remain difficult. While a } \\
\text { broad range of } \\
\text { interventions have } \\
\text { been proposed, there is } \\
\text { a lack of high quality } \\
\text { evidence underpinning } \\
\text { most of these } \\
\text { interventions. } \\
\text { The overview identifies } \\
\text { moderate quality } \\
\text { evidence for the lack of } \\
\text { effectiveness of a } \\
\text { particular type of } \\
\text { intervention. It also } \\
\text { identifies low or very } \\
\text { low quality evidence for } \\
\text { the efficacy of a range } \\
\text { of other interventions. } \\
\text { Readers are } \\
\text { recommended to } \\
\text { interpret this evidence } \\
\text { with caution. }\end{array}$ & $\begin{array}{l}\text { The authors } \\
\text { highlight that } \\
\text { the limitations } \\
\text { of the evidence } \\
\text { base mean that } \\
\text { absence of } \\
\text { evidence for a } \\
\text { range of } \\
\text { specified } \\
\text { treatments } \\
\text { cannot be } \\
\text { interpreted as } \\
\text { evidence that } \\
\text { they are } \\
\text { ineffective. }\end{array}$ & $\begin{array}{l}\text { Since no } \\
\text { rehabilitation } \\
\text { interventions } \\
\text { could be } \\
\text { identified, there is } \\
\text { no anticipated } \\
\text { impact on } \\
\text { rehabilitation } \\
\text { practice. }\end{array}$ \\
\hline $\begin{array}{l}\text { What are the } \\
\text { implications of }\end{array}$ & $\begin{array}{l}\text { Evidence mapped to } \\
\text { identify gaps. }\end{array}$ & $\begin{array}{l}\text { No method described } \\
\text { for identifying specific } \\
\text { gaps in reviews or trials. }\end{array}$ & $\begin{array}{l}\text { Methods describes } \\
\text { evaluation of whether } \\
\text { primary studies are }\end{array}$ & $\begin{array}{l}\text { Evidence and guideline } \\
\text { recommendations are } \\
\text { mapped against a }\end{array}$ & $\begin{array}{l}\text { No method described } \\
\text { for identifying specific } \\
\text { gaps in reviews or trials. }\end{array}$ & $\begin{array}{l}\text { No method } \\
\text { described for } \\
\text { identifying }\end{array}$ & $\begin{array}{l}\text { No method } \\
\text { described for } \\
\text { identifying specific }\end{array}$ \\
\hline
\end{tabular}




\begin{tabular}{|c|c|c|c|c|c|c|c|}
\hline $\begin{array}{l}\text { the findings for } \\
\text { research? }\end{array}$ & $\begin{array}{l}\text { Specific } \\
\text { recommendations for } \\
\text { updates of systematic } \\
\text { reviews, and for further } \\
\text { high-quality RCTs, are } \\
\text { made. } \\
\text { Text states that the } \\
\text { overview is "anticipated } \\
\text { to play a key role in } \\
\text { research prioritisation, } \\
\text { ensuring effective use of } \\
\text { resources, promoting } \\
\text { collaborative working } \\
\text { toward shared priorities, } \\
\text { thereby avoiding } \\
\text { duplication of effort." } \\
\text { Specific } \\
\text { recommendations for } \\
\text { further trials are made. }\end{array}$ & $\begin{array}{l}\text { The overview identifies } \\
\text { the need for new } \\
\text { Cochrane reviews to fill } \\
\text { evidence gaps, } \\
\text { proposing two new } \\
\text { titles. } \\
\text { General } \\
\text { recommendations for } \\
\text { future systematic } \\
\text { reviews relate to review } \\
\text { scope, complexity and } \\
\text { consistency in conduct } \\
\text { and reporting } \\
\text { General } \\
\text { recommendations for } \\
\text { future trials relate to } \\
\text { reporting, reflection of } \\
\text { real world practice, } \\
\text { types of participants, } \\
\text { intervention adherence } \\
\text { and complexity, and } \\
\text { need for 'head to head' } \\
\text { comparisons. }\end{array}$ & $\begin{array}{l}\text { adequate to determine } \\
\text { intervention effectiveness. } \\
\text { Specific recommendations } \\
\text { for new Cochrane reviews } \\
\text { are made. } \\
\text { A range of general } \\
\text { recommendations for } \\
\text { future research are made, } \\
\text { relating to reporting, study } \\
\text { design, participants, } \\
\text { interventions and } \\
\text { outcomes. }\end{array}$ & $\begin{array}{l}\text { framework of } \\
\text { interventions to identify } \\
\text { gaps. } \\
\text { Specific } \\
\text { recommendations for } \\
\text { new reviews and changes } \\
\text { to existing reviews are } \\
\text { made. Need for further } \\
\text { primary research is } \\
\text { addressed within the } \\
\text { 'evidence map' } \\
\text { Areas of clinical practice } \\
\text { that are in most urgent } \\
\text { need of evidence-based } \\
\text { support are highlighted. } \\
\text { General } \\
\text { recommendations relate } \\
\text { to international } \\
\text { collaboration, outcomes } \\
\text { and endpoints, and study } \\
\text { design. }\end{array}$ & $\begin{array}{l}\text { The overview identifies } \\
\text { a clear need for further } \\
\text { research for most } \\
\text { existing treatments and } \\
\text { recommends } \\
\text { international } \\
\text { collaboration. } \\
\text { General } \\
\text { recommendations for } \\
\text { future systematic } \\
\text { reviews include } \\
\text { compliance with the } \\
\text { PRISMA statement on } \\
\text { standards of reporting. } \\
\text { General } \\
\text { recommendations for } \\
\text { future trials are } \\
\text { provided, relating to } \\
\text { diagnostic criteria, } \\
\text { outcomes and reporting } \\
\text { guidelines. }\end{array}$ & $\begin{array}{l}\text { specific gaps in } \\
\text { reviews or } \\
\text { trials. } \\
\text { General } \\
\text { recommendatio } \\
\text { ns for future } \\
\text { research are } \\
\text { provided, } \\
\text { relating to study } \\
\text { designs, } \\
\text { outcomes and } \\
\text { stage of } \\
\text { disease. }\end{array}$ & $\begin{array}{l}\text { gaps in reviews or } \\
\text { trials. } \\
\text { General } \\
\text { recommendations } \\
\text { for future } \\
\text { research are } \\
\text { made, including } \\
\text { recommendations } \\
\text { relating to } \\
\text { outcome } \\
\text { measures. } \\
\text { There are no } \\
\text { statements about } \\
\text { anticipated impact } \\
\text { on rehabilitation } \\
\text { research as such, } \\
\text { although further } \\
\text { studies to treat } \\
\text { fatigue and pain } \\
\text { are } \\
\text { recommended. }\end{array}$ \\
\hline
\end{tabular}

Table III: Summary of intended impact of included overviews 


\begin{tabular}{|c|c|c|c|c|c|c|c|c|c|}
\hline \multirow{2}{*}{$\begin{array}{l}\text { Source } \\
\text { Overview }\end{array}$} & \multirow[b]{2}{*}{$\begin{array}{c}\text { Date of } \\
\text { publication } \\
\text { of full } \\
\text { review }\end{array}$} & \multirow{2}{*}{$\begin{array}{c}\begin{array}{l}\text { Web of } \\
\text { Science }\end{array} \\
\text { TOTAL } \\
\text { CITATIONS }\end{array}$} & \multicolumn{6}{|c|}{ Altmetric } & \multirow{2}{*}{\begin{tabular}{|c|}
$\begin{array}{c}\text { Cochrane } \\
\text { access } \\
\text { data } 2016\end{array}$ \\
$\begin{array}{c}\text { Full text } \\
\text { downloads }\end{array}$ \\
\end{tabular}} \\
\hline & & & $\begin{array}{l}\text { OVERALL } \\
\text { SCORE }\end{array}$ & $\begin{array}{c}\text { News } \\
\text { stories }\end{array}$ & Blogs & $\begin{array}{l}\text { TWITTER } \\
\text { USERS }\end{array}$ & $\mid \begin{array}{c}\text { Facebook } \\
\text { public } \\
\text { wall post }\end{array}$ & $\begin{array}{l}\text { Wikipedia } \\
\text { citations }\end{array}$ & \\
\hline $\begin{array}{l}\text { Interventions for } \\
\text { improving upper } \\
\text { limb function } \\
\text { after stroke }\end{array}$ & $12 / 11 / 14$ & 151 & $92 *$ & 4 & $\begin{array}{c}4 \text { posts } \\
\text { from } 3 \\
\text { blogs }\end{array}$ & 74 & $\begin{array}{c}5 \text { (from } 5 \\
\text { users) }\end{array}$ & 1 & 9847 \\
\hline $\begin{array}{l}\text { Cardiac } \\
\text { rehabilitation for } \\
\text { people with } \\
\text { heart disease }^{41}\end{array}$ & $12 / 12 / 14$ & 19 & $49 *$ & - & - & 68 & 1 & 2 & 3564 \\
\hline $\begin{array}{l}\text { Physical activity } \\
\& \text { exercise for } \\
\text { chronic pain in } \\
\text { adults }^{42}\end{array}$ & $24 / 04 / 17$ & 22 & $85^{*}$ & 1 & 1 & 109 & 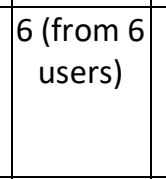 & - & $699^{\$}$ \\
\hline $\begin{array}{l}\text { Interventions for } \\
\text { bronchiectasis }\end{array}$ & $14 / 07 / 15$ & 31 & $27 *$ & - & - & 47 & $6 \begin{array}{c}\text { (from } 1 \\
\text { user) }\end{array}$ & - & 2120 \\
\hline $\begin{array}{l}\text { Interventions for } \\
\text { treating pain and } \\
\text { disability in } \\
\text { adults with } \\
\text { complex regional } \\
\text { pain syndrome }{ }^{44}\end{array}$ & $13 / 04 / 13$ & 55 & $71^{*}$ & f & $\begin{array}{c}3 \text { posts } \\
\text { from } 3 \\
\text { blogs }\end{array}$ & 68 & $\begin{array}{c}8 \text { (from } 7 \\
\text { users) }\end{array}$ & 2 & 4094 \\
\hline $\begin{array}{l}\text { Symptomatic } \\
\text { treatments for } \\
\text { amyotrophic } \\
\text { lateral } \\
\text { sclerosis/motor } \\
\text { neuron disease } \\
\text { (MND) }^{45}\end{array}$ & $10 / 01 / 17$ & 2 & 12 & - & - & 17 & - & - & $405^{\$}$ \\
\hline $\begin{array}{l}\text { Treatments for } \\
\text { chronic } \\
\text { inflammatory } \\
\text { demyelinating } \\
\text { polyradiculoneur- } \\
\text { opathy (CIDP) }\end{array}$ & $13 / 01 / 17$ & 12 & 4 & - & - & 7 & - & - & $330^{\$}$ \\
\hline
\end{tabular}

Table IV: Summary of key access data for the included overviews

*In the top $5 \%$ of all research outputs scored by Altmetric

\$Access data will be based on Cochrane protocol, not full review, as full review published after 2016. 


\begin{tabular}{|c|c|}
\hline Goal. Cochrane overviews should: & Recommendation to achieve goal: \\
\hline $\begin{array}{l}\text { Be designed to avoid research waste, addressing } \\
\text { priority topics / research questions, which have a } \\
\text { clear objective, and where there is a known body } \\
\text { of Cochrane reviews. }\end{array}$ & $\begin{array}{l}\text { Key stakeholders should be involved in identifying } \\
\text { priorities for Cochrane rehabilitation overviews. }\end{array}$ \\
\hline $\begin{array}{l}\text { Clearly signpost readers to where there is } \\
\text { evidence relating to the effect of specific } \\
\text { interventions on important outcomes. }\end{array}$ & $\begin{array}{l}\text { A brief summary (e.g. maximum 2-sided page) } \\
\text { specifically aimed at clearly summarising if there is } \\
\text { evidence of interventions which are beneficial, and } \\
\text { where more details are available. This summary } \\
\text { should be made freely available, easy to access by } \\
\text { intended beneficiaries and easy to share. } \\
\text { Authors are recommended to consult with their } \\
\text { beneficiaries as to the optimum communication } \\
\text { strategy/ strategies to facilitate uptake. }\end{array}$ \\
\hline $\begin{array}{l}\text { Be relevant and accessible to all beneficiaries, } \\
\text { including rehabilitation practitioners, } \\
\text { commissioners, policy makers, educators, } \\
\text { patients, caregivers and families. }\end{array}$ & $\begin{array}{l}\text { Involvement of key stakeholders in the overview } \\
\text { process is recommended, particularly at the } \\
\text { planning/protocol stage, and at the synthesis of } \\
\text { evidence stage to facilitate knowledge translation } \\
\text { and dissemination (see previous recommendation). }\end{array}$ \\
\hline $\begin{array}{l}\text { Describe and implement pre-planned methods } \\
\text { for identifying evidence gaps (only relevant where } \\
\text { a Cochrane overview aims to inform future } \\
\text { research) }\end{array}$ & $\begin{array}{l}\text { The methods for identification of evidence gaps and } \\
\text { generation of research recommendations should be } \\
\text { clearly described in the protocol/methods section. }\end{array}$ \\
\hline Be maintained up-to-date & $\begin{array}{l}\text { Authors should pre-plan strategies for regular } \\
\text { updating of the overview, and consider options for } \\
\text { creating a "living" overview. } \\
\text { Authors should pre-plan strategies for what to do if } \\
\text { the eligible reviews are out of date. }\end{array}$ \\
\hline $\begin{array}{l}\text { Clearly state impact goals relating to societal, } \\
\text { economic and academic impacts, beneficiaries } \\
\text { and potential pathways to impact, including } \\
\text { strategies for dissemination beyond publication } \\
\text { of the overview within the Cochrane Library }\end{array}$ & $\begin{array}{l}\text { At the protocol stage, authors should clearly state } \\
\text { impact goals and beneficiaries, with consideration of } \\
\text { pathway to impact. } \\
\text { Develop, with input from key stakeholders, a } \\
\text { detailed knowledge translation strategy for the } \\
\text { overview. This should clearly address stated impact } \\
\text { goals and identified pathways to impact. Publish this } \\
\text { in the protocol/methods and implement this plan. }\end{array}$ \\
\hline $\begin{array}{l}\text { Propose methods aimed at capturing and } \\
\text { evaluating impact of overviews }\end{array}$ & $\begin{array}{l}\text { Impact goals, and methods of evaluation, should be } \\
\text { clearly identified within the protocol/methods. }\end{array}$ \\
\hline
\end{tabular}

Table V: Recommendations for future overviews 


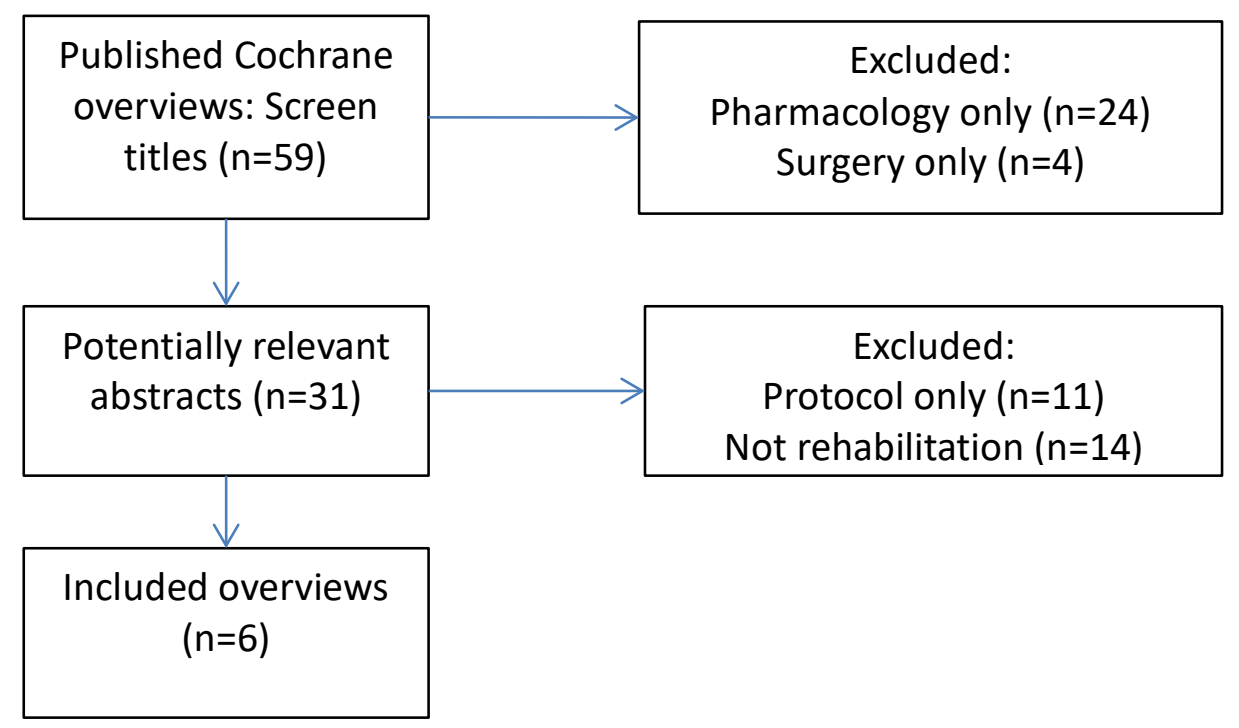

Figure 1: PRISMA diagram, showing search results 


\section{GOAL: INFORM FUTURE RESEARCH}

BENEFICLARIES: Researchers, research funders and commissinners

POTENTLL WAPACT. Raised awareness" mprowed engagement in research", supported funding apolicabons intuenced funding decisions"

ACTICNS REQUAFE; Provide accurate, up to date, accessble, comprehensive, relevark documenctaion. Publish clear statements of what further research is required $\left\langle(\mathrm{r} \text { amp }\rangle_{\text {present }}\right.$ at hey corferences \& events,

Engoge with researchers and research funders.

\section{GOAL: SUPPORT CLINICAL DECISION MAKING \\ EENEFICLARIES Heath and Social Care practioners} professional bodies and professional networks, patients, carers. familes.

POTENTVAL MPACT Raised awareneses, enhenced knowedge and understanding, informed guiblines and recommendations? provided resources and trainingt, irformed decision makingt, improved practice.

ACTIONS REQUREO: Provide axcurate, $\varphi$ to date, accessbie comprehensive relevart documentation, signpast reviews with evidence of effective interventions. design and delwer protessional education.

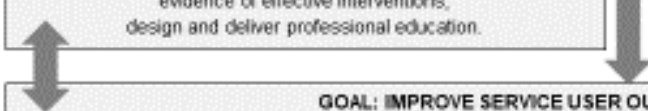

BENEFICLARIES Patients, carers, familes.

POTENTLA IMPACT: Risised awsreness" : pravided resources"i, receipt of aptimal rehabiltation treatment" improved cinical autcames and experiences" improved quality of life impraved engsgement in reserch"

ACTONS REQURED Engage serice users in research and dssemination. Provide sccessible relevort information and resources. Faciltate impost from other actions

satentiar sociefareconamic impact

- Patentiai academic mpact

\section{Figure 2: Pathway to impact}

